\title{
RUDOLF SCHNACKENBURG - BIBLISTA Z KATOWIC. WYSTAWA Z OKAZJI SETNEJ ROCZNICY URODZIN BIBLISTY. (17 STYCZNIA 2014 ROKU. WYDZIAL TEOLOGICZNY UNIWERSYTETU ŚLĄSKIEGO W KATOWICACH)
}

W dniu 17 stycznia 2014 roku w auli Wydziału Teologicznego Uniwersytetu Śląskiego w Katowicach miała miejsce konferencja naukowa Życie i twórczość Rudolfa Schnackenburga. Sesja naukowa z okazji setnej rocznicy urodzin. Otwarcia konferencji dokonał dziekan Wydziału Teologicznego Uniwersytetu Śląskiego ks. dr hab. Antoni Bartoszek. Sympozjum składało się z części biograficznej i teologicznej, w których referaty wygłosili pracownicy Zakładu Teologii Biblijnej Starego i Testamentu, a także prelegenci z innych ośrodków akademickich takich jak Katolicki Uniwersytet Lubelski Jana Pawła II w Lublinie i Katolicki Uniwersytet w Ružomberku na Słowacji.

Konferencji towarzyszyła wystawa tematyczna przygotowana przez pracowników Biblioteki Teologicznej we współpracy z pracownikami Zakładu Teologii Biblijnej. Materiał wystawienniczy został przygotowany ze zbiorów Biblioteki Teologicznej UŚ oraz użyczony na czas trwania ekspozycji ze zbiorów Biblioteki Wydziału Teologicznego Uniwersytetu Opolskiego, a także prywatnych księgozbiorów ks. prof. Stanisława Pisarka i ks. dr hab. Artura Maliny.

Rudolf Schnackenburg urodził się w Katowicach 5 stycznia 1914 roku. Jego ojciec był ewangelikiem, a matka katoliczką. Krótko po wybuchu I wojny światowej, po śmierci ojca wraz z matką i młodszym bratem przeprowadził się do Legnicy. Po ukończeniu gimnazjum legnickiego w 1932 roku podjął studia na Wydziale Teologii Katolickiej Uniwersytetu Wrocławskiego. Swięcenia kapłańskie przyjął 1 sierpnia 1937 roku z rąk kard. Adolfa Bertrama'. W latach 1937-1946 pracował jako duszpasterz we Wrocławiu, a później w Złotoryi. W 1937 roku uzyskał tytuł doktora teologii na Uniwersytecie Wrocławskim na podstawie rozprawy Der Glaube im vierten Evangelium.

W 1946 roku ówczesne władze Polski Ludowej zmusiły go do opuszczenia

\footnotetext{
${ }^{1}$ Handbuch des Erzbistums Breslau für das Jahr 1937, Breslau 1937, s. 189.
} 
naszego kraju ze względu na jego niemieckie pochodzenie. Wraz z innymi profesorami przeniósł się do Niemiec na uniwersytet monachijski, gdzie pracował jako samodzielny pracownik naukowy (1948-1951). W 1947 roku uzyskał stopień doktora habilitowanego na postawie rozprawy Das Heilsgeschehen bei der Taufe nach dem Apostel Paulux. Eine studie zur paulinischen Teologie (Zbawienie przy chrzcie według apostoła Pawła. Studia nad teologią Pawłową). Od 1952 roku zatrudniony był jako profesor nadzwyczajny egzegezy w Kolegium FilozoficznoTeologicznym Dillingen oraz w Bambergu. W 1957 roku przeniósł się na uniwersytet do Würzburga gdzie kierował katedrą egzegezy Nowego Testamentu. Jego seminaria naukowe z Nowego Testamentu cieszyły się bardzo dużym zainteresowaniem, czego dowodem była znacząca liczba doktorantów i habilitacji jego uczniów z 22 krajów.

Ważną sprawą dla Schnackenburga było ekumeniczne pojednanie chrześcijan. Wyrazem uznania dla jego ekumenicznych zainteresowań było powierzenie mu na okres jednego roku funkcji przewodniczącego w Międzynarodowym Stowarzyszeniu Nowotestamentalistów należącym do różnych denominacji chrześcijańskich Studiorum Novi Testamenti Societas. W latach 1958-1963 uczestniczył w roli konsultora w pracach Papieskiej Komisji Biblijnej. Następnie pełnił funkcje doradcy w Sekretariacie do Spraw Jedności Chrześcijan. Od 1968 roku był członkiem Międzynarodowej Papieskiej Komisji Teologów wspierającej prace Kongregacji Nauki Wiary.

Uhonorowaniem jego działalności naukowej było otrzymanie w 1970 roku tytułu doktora honoris causa Fakultetu Teologicznego Uniwersytetu w Innsbrucku. Ks. Rudolf Schnackenburg zmarł 28 sierpnia 2002 roku w Erlabrunn koło Würzburga w 88 roku życia i 65 roku kapłaństwa.

Na wystawie zorganizowanej w holu Wydziału Teologicznego UŚ zaprezentowano pozycje z bogatego dorobku naukowo-badawczego Schnackenburga odzwierciedlające główne zainteresowania naukowe biblisty: tradycję Janową (Czwarta Ewangelia i Pierwszy List św. Jana), chrystologię Ewangelii, eklezjologię oraz teologię moralną Jezusa i pierwotnego Kościoła².

Zgromadzony materiał został podzielony na kilka bloków tematycznych, które zostały zaprezentowane $\mathrm{w}$ gablotach wystawienniczych.

W pierwszej witrynie znalazły się dokumenty biograficzne przybliżające sylwetkę i główne wydarzenia z życia biblisty; m.in. biogramy, które zamieszczone zostały w leksykonach i słownikach m.in.: Leksykonie wielkich Teologów XX i XXI wieku (red. J. Majewski, J. Makowski, Wrocław 2003), Neue Deutsche Biographie (ed. H. Hockerts, Berlin 2007), Biographisch-bibliographisches Kirchenlexikon (ed. F. Bauz, 1979-) oraz Lexikon für Teologie und Kirche W. Kasper, Freiburg-Basel 1993-). W gablocie umieszczony został także plakat informujący o zorganizowanej na Wydziale Teologicznym Uniwersytetu Śląskiego sesji naukowej poświęconej bibliście. Ciekawym uzupełnieniem informacji biograficznej były fotografie kamienicy, w której urodził się ks. Rudolf (jedna przedstawiała

2 J. Juroszek, Kim byt Rudolf Schackenburg?, GN z 17.01.2014. http://katowice.gosc.pl/ doc/18533300.Kim-Byl-Rudolf-Schnackenburg/2, 27.02.2014. 
stan budynku sprzed stu lat, druga obecny wygląd kamienicy) oraz kopia odpisu aktu urodzenia Schnackenburga, będąca dowodem jego polskiego pochodzenia.

W kolejnej gablocie przedstawiono informacje dotyczące pracy naukowej i dydaktycznej Schnackenburga. Zamieszczono w niej m.in. wykaz publikacji biblisty w Würzburga, który liczy ponad 40 książek, niemal 160 artykułów, dziesiątki haseł w różnych słownikach i leksykonach oraz setki recenzji prac naukowych. Świadectwem uznania i więzi uczniów ze swoim mistrzem egzegezy Nowego Testamentu są dwie księgi pamiątkowe wydane z okazji kolejnych rocznic urodzin Schnackenburga Neueus Testament und Kirche: [Festschrift] für Rudolf Schackenburg zum 60. Geburstag Am 5. Januar 1974 von Freudem und Kollegen gewidmet. Freiburg 1974; Neuen Testament und Ethik: [Festgabe] für Rudolf Schackenburg, Freiburg 1989). Obejmują one łącznie ponad 80 artykułów dedykowanych bibliście, autorstwa teologów różnych kościołów chrześcijańskich.

Następna witryna zawierała materiały świadczące o kontaktach Schnackenburga z Polską i percepcji jego dorobku w naszym kraju. Zaprezentowano polskie tłumaczenia publikacji biblisty z Würzburga, wśród których znajdują się m.in.: książka (Nauka moralna Nowego Testamentu w thumaczeniu F. Dylewskiego, Warszawa 1993), artykuły Kim byt Jezus z Nazaretu?, tłum. J. Zychowicz, zamieszczone w czasopiśmie „Znak” z $1978 \mathrm{nr} 4-5$, s. 485-548 oraz A Stowo stało się Ciatem dotyczący prologu do Ewangelii św. Jana opublikowany w „Communio" z 1983 nr 5, s. 19-28. W gablocie tej znalazły się również recenzje polskich biblistów wszystkich ważniejszych jego dzieł. Ważnym materiałem źródłowym był tekst referatu Das kirchliche Amt nach Eph 4,7-16, jaki Schnackenburg wygłosił w czerwcu 1972 roku w Krakowie podczas Kongresu Biblijnego ${ }^{3}$. Szczególnym świadectwem kontaktów Schnackenburga z polskimi biblistami były zaprezentowane książki z dedykacją autorską ofiarowane ks. prof. S. Pisarkowi w dowód wdzięczności za udzieloną gościnę i serdeczne przyjęcie podczas pobytu w Polsce w 1972 roku (Messagio morale del Nuovo Testamento, Alba 1971; L'Essistenza cristiana il Nuovo Testamento, Modena 1972).

W dalszej części wystawy zaprezentowano publikacje dotyczące tradycji Janowej - głównego obszaru badań i zainteresowań naukowych Schanckenburga. Należy do nich określany dziełem życia Schnackenburga - Komentarz do Ewangelii św. Jana oraz Komentarz do Pierwszego Listu św. Jana (Die Johannesbriefe, Freiburg im Breisgau 1954). Praca nad Komentarzem do Ewangelii św. Jana trwała dziesięć lat. Dzieło to obejmuje trzy tomy, wydawane kolejno w latach 1965, 1971 i 1975 Das Johannesevangelium. Teil 1. Einleitung und Kommentar zu Kapitel 1-4, Freiburg im Breisgau, 1965; Das Johannesevangelim. Teil II. Kommentar zu Kapitel 5-12, Freiburg im Breisgau 1971; Das Johannesevangelium, Teil III. Kommentar zu Kapitel, 13-21, Freiburg im Breisgau 1975). Łącznie ponad 1500 stron omawiających Czwartą Ewangelię. W 1984 roku komentarz został uzupełniony o tom czwarty zawierający ekskursy Das Johannesevangelium. Teil IV Ergaanzende und Exkurs, Freiburg im Breisgau 1984. Współwydawcą komen-

${ }^{3}$ Materiały Kongresu Biblijnego w Krakowie (6-8 czerwca 1972 r.), oprac. S Grzybek, J. Chmiel, Kraków 1974. 
tarza był Anton Vogtle, a pozycja ukazała się nakładem wydawnictwa Herder w liczącej się serii komentarzy teologicznych do Nowego Testamentu (HThKNT).

W następnej gablocie zamieszczono pozostałe ważniejsze publikacje Schanckenburga: dwutomowe opracowanie teologii moralnej Nowego Testamentu i pierwotnego Kościoła (Die sittiche Botschaft des Neuen Testaments, Bd. 1, Von Jesus zur Urkirche, Freibug im Breisgau 1986; Bd. 2, Die urchristlichen Verkündiger, Freiburg im Breisgau 1988), pozycję poświęconą teologii Nowego Testamentu (Neuetestamentliche Theologie: der Stand der Forschung, Leipzig 1961), a także książki z zakresu eklezjologii (Gottes Herrschaft und Reich, Eine biblischtheologishe Studie, Freiburg im Breisgau 1969; Die Kirche im Neuen Testamente, Questiones disputatae 14, Freiburg im Breisgau 1963), komentarz do Listu do Efezjan (Der Brief an die Epheser, EKK 10, Zurich 1982). Wśród komentarzy na uwagę zasługuje dwutomowy komentarz do Ewangelii św. Marka Das Evangelium nach Markus. Band 1-2, Geistliche Schriftlesung. Erläuterungen zum Neuen Testament für die Geistliche Lesung, (Leipzig 1966) oraz dwutomowy komentarz do Ewangelii św. Mateusza Matthausevangelium 1-16,20, Band 1, (Würzburg 1999); Matthausevangelium 16,21-28,20, Band 2, (Würzburg 2000).

Kolejna witryna prezentowała dwie serie wydawnicze komentarzy, których Schnackenburg był współredaktorem: Komentarz do Nowego Testamentu wydawnictwa Herder oraz Ewangelicko-Katolicki Komentarz do Nowego Testamentu. Seria wydawnictwa Herder (Herders theologischer Kommentar zum Neuen Testament - HThKNT) została zainicjowana w 1953 roku przez A. Wikenhausera, a następnie kontynuowana przez A. Vogtle i R. Schnackenburga, którzy dbali, by autorzy poszczególnych opracowań należeli do najwybitniejszych niemieckich katolickich biblistów. Z kolei ewangelicko-katolicki komentarz do Nowego Testamentu (Evangelisch Katholischer Kommentar zum Neuen Testament - EKK) jest owocem ekumenicznego zaangażowania Schnackenburga. Z pomysłem ekumenicznego komentarza wyszedł biblista protestancki z Zurichu - Albert Schwaizer, po stronie katolickiej została ona podjęta z radością przez Schnackenburga. Do współpracy zaproszono także protestanta Ulricha Wilckensa i katolika Josefa Blanka ${ }^{4}$.

Dalsza część ekspozycji ukazuje publikacje współredagowane przez Schanckenburga, w tym biblijny periodyk „Biblische Zeitschrift”, Lexikon für Theologie und Kirche oraz nowy przekład Biblii niemieckiej Einheitubersetzung (EU). Dzięki bibliście z Würzburga półrocznik „Biblische Zeitschrift”, którego od 1957 roku był współwydawcą, osiągnął wysoką pozycję wśród międzynarodowych czasopism naukowych w zakresie egzegezy. Udział Schnackenburga w powstaniu drugiej edycji Lexikonu für Theologie und Kirche obejmował doradztwo z zakresu teologii. Na szczególną uwagę zasługuje nowy przekład Biblii niemieckiej Einheitubersetzung.(EU). W którego wykazie thumaczy ksiąg Nowego Testamentu figuruje Schnackenburg. Wartość tego tłumaczenia rozpowszechnionego wśród niemieckojęzycznych katolików podkreśla fakt, że przyjmuje ją również Kościół ewangelicki Niemiec w zakresie Nowego Testamentu i Księgi Psalmów.

${ }^{4}$ S. Pisarek, Rudolf Schnackenburg (1914-2002) - wspomnienie pośmiertne, SSHT 2003, t. 36, s.577-581; 
Ostatnia gablota dokumentowała pozycje o rysie duszpasterskim Schnackenburga. Wśród zamieszczonych tam książek znalazły się m.in. medytacje i rozważania biblijne, oraz opracowania popularnonaukowe kwestii biblijnych przygotowane z myślą o kaznodziejach i katechetach Nachfloge Christi- heute : Antworten und Weisungen aus dem Neuen Testament, Leipzig 1970; Die Geburt Christi ohne Mythos und Legende, Mainz 1969; Sulla nascita di Cristo: meditazioni teologiche, Brescia 1970; Dio ha inviato il suo Figlio: il mistero del Natale, Brescia 1991; Freundschaft mit Jesus, Freiburg-Basel 1995; Der Jesusweg. Meditationen zum Lukanischen „Reisebericht”, Stuttgart 1990; Deutet die Zeichen der Zeit. Meditationen zum Advent, Freiburg 1976.

Wystawa prezentowana na Wydziale Teologicznym UŚ przybliżyła postać Rudolfa Schnackenburga, cenionego biblisty, uznanego przez Benedykta XVI za najwybitniejszego niemieckojęzycznego egzegetę drugiej połowy $\mathrm{XX}$ wieku ${ }^{5}$. Ekspozycja, która towarzyszyła konferencji naukowej stanowiła dopełnienie treści przedstawionych $\mathrm{w}$ referatach. Ponadto dla upamiętnienia tego wydarzenia zamieszczono dokumentację fotograficzną na stronie internetowej Biblioteki Teologicznej UŚ.

${ }^{5}$ J. Ratzinger, Jezus z Nazaretu, Kraków 2007, s. 6. 